Back in France, Barthes wrote one article on China, but never the book he was planning on the last page of Notebook 3. As for Tel Quel, it devoted its autumn 1974 issue to the trip, but afterward moved away from its Maoist stance. By the end of the 1970s, it was exploring theological questions, perhaps not a surprising development considering that Barthes and Sollers were both Jesuit-educated, while Kristeva had been schooled by Dominican nuns. It ceased publication altogether in 1982, by which time China had also left Mao far behind, and it is ironic to reflect that the first Frenchmen to encounter China were Jesuits sent by Louis XIV, three centuries before. What Barthes would ultimately have made of his trip is unknown, since he was killed by a Parisian laundry van in 1980 , but he had by then decided that Marxism was just as guilty of creating mythological stereotypes as bourgeois culture. Hence, the trip appears to have been a critical experience in the lives of its participants, since they changed after it. Barthes's notebooks are, in the final analysis, a record of a highly unusual East-West encounter that took place in a bygone era.

\title{
H. Swindall
}

H. Swindall is a professor of English at Pusan National University in South Korea.

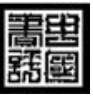

Hok-lam Chan. Ming Taizu (r. 1368-98) and the Foundation of the Ming Dynasty in China. Variorum Collected Studies Series. Burlington, VT: Ashgate Publishing Co., 2011. vii + 348 pp. Hardcover £95.00, ISBN 978-1-4094-3128-2.

This variorum collection of eight articles written by Hok-lam Chan, all focused on Zhu Yuanzhang and the early years of the dynasty he founded, comes to us in the same year as his passing. For anyone interested in the Ming dynasty, this will be an important collection of seminal works. One of the great assets of these Variorum Collected Studies volumes is that they bring together articles that may be difficult to obtain or little known outside of specialist circles. This volume is particularly helpful since it selects some of the most outstanding studies by Hok-lam Chan on the focused period of the early Ming. This is important because Hok-lam Chan's erudition extended well beyond the Ming, and he was prodigious in his writing. Hok-lam Chan began his professional work of some forty-four years researching the non-Han conquest dynasties Jin and Yuan, only later moving into the Ming era. A brief scan through a recently published 
bibliography of Chan's work indicates his catholic interests and enormous productivity; he authored some nine monographs and collections and ninety essays and articles in Chinese. His English-language contributions were equally prolific with twelve monographs or collections and fifty-eight essays and articles. ${ }^{1}$

The first of the eight articles reprinted here, “The 'Song' Dynasty Legacy: Symbolism and Legitimation from Han Liner to Zhu Yuanzhang of the Ming Dynasty," was originally published in 2008. The article examines the symbolic legitimation of the new Ming dynasty, both in its own right and as understood and portrayed by the historian Wu Han (1909-1969). Chan's careful study of Zhu Yuanzhang's legitimizing strategy shows that it was based on and responded to two earlier anti-Mongol states that preceded the Ming, both of which invoked and pretended to restore the Song dynasty. Chan argues that while Zhu owed his own political success to his initial affiliation with Han Liner's rump Song state, he also found it necessary to dissociate himself from that regime. He decreed that the Song cosmic cycle had run its course, and he adopted the title Ming to signify that shift. At the same time, he embraced fire and red as symbols of his own political identity and legitimacy, and in doing so he decoupled those symbols from the age-old formula of the cyclic rotation of cosmic powers in the Five Agents theory.

Chan then goes on to discuss the erroneous association of the dynastic title Ming with Manichaeism as emanating from the historian Wu Han. Through careful historiography, Chan shows that association could not have been the case. Rather, we need to understand the dynastic title Da Ming as a reference to the Great Radiance in which the Amida Buddha, as the king of the Radiant Buddhas, is seen. ${ }^{2}$ Zhu Yuanzhang's choice of Da Ming "simultaneously dislodged his political linkage to the Han-Song regime and paid homage to the Mingwang messianic legacy of the White Lotus-Maitreya sect on the one hand, and the Confucian state worship to the sun and moon to seek Heaven's blessings on the other." ${ }^{3}$ Thus, Zhu Yuanzhang was, indeed, a crafty and pragmatic politician.

In the next article in this collection, "Naqaču the Grand Marshall, a Mongol Warlord in Manchuria during the Yuan-Ming Transition," published in 2009, Hok-lam Chan looks at the transition from Yuan to Ming through the lens of events managed by this prominent Mongol general. This study is interesting not least because Chan makes extensive use of the official Koryo dynastic history (Koryo sa) as well as the Ming Taizu shilu. Naqaču's story is fascinating on its own because he became a powerful independent warlord in the Liaodong Peninsula. Chan's treatment also reveals the contours of relations between Koryo and the newly emergent Ming state and explains how this Mongol loyalist mastered diplomatic and military strategies to exploit the interests of the Mongols, the Koreans, and the Chinese.

The earliest article in this collection is the third, "Two Ming Biographies," published in 1975. These are translations by Chan of biographies of two semileg- 
endary Daoist religious personages. His interest in these men stems from the fact that both biographies were incorporated into Ming Taizu's reign chronicles and their stories were adapted and embroidered by later popular writers. The first biography, that of the "Crazy Chou Immortal," tells the story of a Daoist who impressed the future Ming founder by his pronouncement of the imminent advent of an era of great peace in the waning days of the Yuan. ${ }^{4}$ Zhu Yuanzhang wrote the biography, and the text conveys a vivid picture of Crazy Chou predicting Zhu Yuanzhang's victory over his adversary Chen Youliang in a naval battle on Lake Poyang.

"Iron-cap Master Chang Chung" was written by the early-Ming scholar Song Lian. It paints a picture of this Daoist as having been responsible for bringing up a fierce windstorm that helped Zhu defeat Chen Youliang. Chan's translation of these two biographies is interesting because they tell us a lot about the role of Daoist ideas and folklore in the founding of the Ming. Chan's careful study also provides details about the language of these two texts: the first as direct and forceful but semiliterate, fitting for the author, while the second was obviously the product of a man of letters. Chan ends his translations with more biographical information about both men. I could easily see this article being useful for students of lateimperial Chinese literature as well as for reading in Ming political history.

The fourth article in this collection is a 1995 publication titled "Ming T'ai-tsu's Manipulation of Letters: Myth and Reality of Literary Persecution." Chan takes on the charges that the Ming founder persecuted many scholar-officials because they offended him by using improper language in their court memorials or communications. The subtext of these charges is that Ming Taizu was essentially illiterate, a man who found offense in writings that were actually laudatory. The executions that Ming Taizu are alleged to have caused were not, however, written about in official literature, but were actually transmitted via popular miscellanies. Chan first shows us that it was actually late Qing scholars whose studies provide the basis for a reappraisal of these allegations. He takes the reader through a detailed study of the allegations and who wrote them. His conclusion is that while the stories cannot be used as reliable sources of information to validate whether the literary persecutions occurred, neither should they be entirely dismissed because they do provide us with a sense of the personality of Ming Taizu and how he was viewed by the literati and, perhaps, also by the larger populace later on.

In fact, the records of literary persecutions suggest that Ming Taizu, far from being illiterate, may have been "a notorious manipulator of letters" who was cognizant of how he and his reign would be seen by later generations. ${ }^{5}$ The really substantive issues at play here concern early Ming historiography. Chan shows through ample evidence that it was nearly impossible for private historians to write any kind of reliable history about the early Ming period. He explains why the allegations of literary persecutions were accepted by later historians: They had no way to verify the sources even had they had doubts about the claims. Chan also 
makes two salient and worthwhile arguments about the appearance of these accounts that historians and literary scholars will find of interest. First, he shows that these stories of literary persecutions was spurred by the rise of a new genre of pseudo-historical, semifictional miscellanies that were written for a wider public audience, who existed thanks to the growth in literacy. Second, the proliferation of these stories was due to a marked relaxation of the taboo of writing about the early Ming by the sixteenth century. Chan, in typical fashion, does not end his study here. Always cognizant of his role as a teacher, he helpfully ends by going beyond the stories themselves to the more profound issue of how a historian can and should use this type of material to appreciate and assess different levels of meaning embedded in a source without falling into the trap of becoming circumscribed by one argument, kind of evidence, or narrative. We can learn a lot about the personality of the Ming founder, the political atmosphere of his time and of the later Ming, and also about popular conceptions of the Ming founder in these stories.

The fifth article, "Ming Taizu’s 'Placards' on Harsh Regulations and Punishments Revealed in Gu Qiyuan's Kezuo zhuiyu," is a 2009 study of the nature of the Ming legal code. Chan argues that Ming law and jurisprudence were as much informal in nature as the product of a set of formal legal codes and strict bureaucratic process. This was because Ming Taizu had a habit of proclaiming commands and penalties as grand pronouncements posted on placards that were displayed in government offices, public markets, and pavilions erected specifically to display them in villages. As Chan's study eloquently demonstrates, Ming Taizu's pronouncements of extralegal punishments were quite regular and common, and they need to be studied if one wishes a full appreciation of the way that law functioned to regulate Ming society. This study is far from exhaustive, as Chan readily admits, and consists of translations of sample placards found in one chapter of a Ming miscellany.

This study is useful for several reasons. It shows us the underbelly of Ming law at work; it also reveals something of Ming Taizu's complex character and how he used social engineering to satisfy his own whims and needs, and underscore the tyrannical nature of society under his control. Scholars interested in Ming legal and even literary history will be interested in this article for all of these reasons. It is also highly satisfactory that Chan produced the original Chinese text, with punctuation, alongside his translation.

We next go to Zhu Yuanzhang's descendants in the sixth article, "Ming Taizu's Problem with His Sons: Prince Qin's Criminality and Early-Ming Politics," from 2007. This is an in-depth study of the life and crimes of Zhu Yuanzhang's second son by his empress $\mathrm{Ma}$, all the more interesting because he has no official biography in the official dynastic history. Chan's reconstruction of the story from entries in the Taizu shilu makes for gripping reading, including some thirty-seven indictments against the prince for a wide array of offenses, two letters to the prince from 
his father recommending remedial action, and a funeral ode for the prince also written by his father.

What emerges from Chan's close study of these documents is a picture of Ming Taizu as an extremely lenient father to his sons, in spite of his legacy as a violent, autocratic ruler. It is clear that Taizu was very concerned about his legacy and the continuation of his line, and so he tried to set up an enfeoffment system that would regulate and coordinate the principle of succession. Chan's use of the sources also sheds light on the reasons behind Taizu's persecution of his powerful generals and high officials in the last years of his reign, and the fact that later Ming emperors could not find a way around the problems inherent in the enfeoffment system.

The next article, the seventh, was published in 2009 but had its origins in Chan's doctoral dissertation written back in 1967. "The Making of a Myth: Liu Jis Fictionalization in the Yinglie zhuan and Its Sequel" deals with some of the same issues as the previous article, the fate of Ming Taizu's grandson, Zhu Yunwen (the Jianwen emperor), after the prince of Yan (Zhu Di) usurped his power and grabbed the throne as the Yongle emperor. Here the subject of study is Zhu Yuanzhang's chief adviser, Liu Ji (1311-1375), and his eventual description in a late Ming novel as a Daoist political and military strategist, adviser, and magical prognosticator. Liu Ji's prophecies about the fate of Taizu's grandson led the Jianwen emperor to escape death by disguise as a Buddhist monk, living safely to old age, out of Zhu Di’s reach.

In addition to learning about the historical Liu Ji and other important persons of the period, Chan's study has a lot to teach us about the uses of popular literature, Daoism, and the general process of dramatization where historical personages were transformed into mythic heroes in popular literature of the time, especially historical novels. Typical of Chan's scholarship, it is an exhaustive study of the primary sources. The result is a highly accessible account that will be of interest to a wide range of readers. This study also reflects Chan's early training in Chinese literature.

The eighth article in this collection, also the longest at eighty-three pages, follows the chronological trajectory set up in the previous two articles by focusing on the efforts of Ming Taizu's fourth son to legitimate his usurpation of the accession to the throne of Taizu's grandson and appointed successor, Zhu Yunwen. The 2007 article, "Legitimating Usurpation: Historical Revisions under the Ming Yongle Emperor (r. 1402-1424)," is not only an important part of Chan's scholarship on the early Ming. It also continues Chan's groundbreaking work on the processes of legitimization of imperial power in late imperial China, which he first explored in his 1984 book on Jurchen efforts to legitimize their conquest dynasty. ${ }^{6}$ In typical fashion, Chan methodically examines all of the historical records that the third Ming emperor caused to be changed to justify his actions against the second Ming emperor and thus legitimize his accession to the throne. After a careful study of 
these texts, Chan then goes on to discuss how and why later Ming emperors continued to uphold Yongle's claims.

What emerges is a picture of a man obsessed with his own power, which explains how he could legitimize his brutal acts. Not only did Zhu Di use all of the tricks that other usurpers of power had used in earlier times, but he also manipulated the ancestral rules set up by his own father, even as he invoked those same rules to justify his own actions (the Huang Ming zuxun). His actions reveal, perversely, that Ming Taizu's ancestral rules continued to be central to all Ming emperors as a primary source of legitimacy of their power and authority. Zhu Di could not get around them, so he undertook a systematic revision and/or destruction of the records of his predecessor's reign to produce versions that supported his acts and accorded with Taizu's rules. Chan concludes this important study by asserting that it is necessary for historians interested in late Ming political and social history to go back to the traditions set by the Ming founder, such as the ancestral injunctions, since these continued to define the criteria for political legitimacy for all Ming emperors.

In sum, this variorum collection is an important contribution to the field of Ming studies because it brings under one cover eight of Hok-lam Chan's most important studies of early Ming history. It is also a nice complement to an earlier variorum collection of Chan's work on the Mongols in China. ${ }^{7}$ This collection is not perfect; as Chan acknowledges in the preface, written only a few months before his passing, there are two important articles on Ming Taizu's historiography not included here. But he provides helpful citations for those articles. The eight articles included cover a lot of important ground based in the early Ming and its founder. Anyone interested in late imperial Chinese political, intellectual, religious, and literary history will find this collection of great value.

Michael C. Brose

Michael C. Brose is an associate professor of history in the Department of History at the University of Wyoming. He specializes in Mongol Yuan social history and the history of Islam in Yunnan.

1. See "Bibliography of the Works of Hok-lam Chan," Journal of Song-Yuan Studies 41 (2011): xiii-xxv.

2. "The 'Song' Dynasty Legacy: Symbolism and Legitimation from Han Liner to Zhu Yuanzhang of the Ming Dynasty," Harvard Journal of Asiatic Studies 68 (2008): 122; reprinted here as article.

3. Ibid., p. 123.

4. "Two Ming Biographies: The Crazy Chou Immortal and the Iron-cap Taoist," Renditions 4 (1975): 85-90; reprinted here as article.

5. "Ming T'ai-tsu's Manipulation of Letters: Myth and Reality of Literary Persecution," Journal of Asian History 29 (1995): 41; reprinted here as article. 
6. Hok-lam Chan, Legitimation in Imperial China: Discussions under the Jurchen-Chin Dynasty (1115-1234) (Seattle: University of Washington Press, 1984).

7. Hok-lam Chan, China and the Mongols: History and Legend under the Yüan and Ming. (Burlington, VT: Ashgate Publishing Co., 1999).

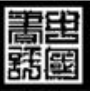

Xi Chen. Social Protest and Contentious Authoritarianism in China.

New York: Cambridge University Press, 2012. 256 pp. Hardcover \$95.00, ISBN 978-1-107-01486-2.

In most studies of social movement in China and elsewhere, protest and authoritarianism are often treated as two contradictory phenomena. Contentious authoritarianism, therefore, seems to be a contradiction in term. Xi Chen, however, has made an intriguing case in this book about how the Chinese Communist Party (CCP) has been tolerating or even facilitating contentious politics from below to help maintain its authoritarian rule.

The questions that the book addresses have been dealt with by many other authors: What accounted for the surge of social protests all over China in the 1990 s and how did the CCP survive it? Many authors have given many different answers. Some argue the CCP dealt with these protests by repressing them selectively. It repressed those that started to spill over beyond a local region and develop coalitions with dissident intellectuals or those that manifested political demands, but it left the other self-limiting local protests with pure livelihoods demand alone. Some argue the ultimate source of stability of the CCP rule is the rapid economic growth and the performance legitimacy that such growth confers to the regime.

While all these previous works are asking why the CCP rule survived despite widespread protest and discontent, Chen's novel argument is that the CCP rule survived because of such widespread protest. The core point of the book is that "[be]neath the surface of noise and anxiety [of protest], the whole political system remains stable." As with these protests, "most disgruntled social groups can find a space for interest articulation" that makes the whole system more sustainable (p. 5).

After reviewing in the introduction the limitations of existing social movement literature in understanding the recent wave of Chinese protests, Chen uses the government data on petitions at the Hunan and Henan provinces to map in chapter 2, "The Surge in Social Protests from a Historical Perspective," the trend of 